\title{
The effect of Cuscuta babylonica Aucher (Cuscuta) parasitism on the phenolic contents of Carthamus glaucus Bieb.subsp. glaucus
}

\author{
Hilal SURMUŞ ASAN ${ }^{1}$, Hasan Çetin ÖZEN ${ }^{1}$
}

\begin{abstract}
Cuscuta species are holoparazit plants which obtained all need water and organic material from host plants. The host plants are generally synthesized a variety of phenolic compounds in response to attack of parasitic plants. In this study, the plant Carthamus glaucus Bieb. subsp. glaucus (Compositae) used as host plant is an important plant that contains several compounds inhibit the STAT-3 gene is directly related to prostate cancer. In the study it was investigated that the effect of Cuscuta babylonica parasitism phenolic compounds of C. glaucus. The phenolic compounds of infected and uninfected C.glaucus plants analysed by LC/MS-MS. The results indicated a rise in phenolic contents that known as defense chemicals quinic acid, gallic acid, tr-caffeic acid, hyperoside, quercetin, and naringenin with dodder infestation. Besides in the content of tr-aconitic acid, vanillin, hesperidin, 4-OH-benzoic acid, salicylic acid and kaempferol decreased after dodder infestation.
\end{abstract}

Keywords: Cuscuta babylonica Aucher, Carthamus glaucus bieb. subsp. glaucus (Compositae), phenolic compound, LC/MS-MS

\section{Cuscuta babylonica Aucher (küsküt) parazitliğinin Carthamus glaucus Bieb.subsp. glaucus'un Fenolik İçeriği Üzerine Etkisi}

ÖZET: Küsküt türleri, ihtiyaçları olan tüm su ve organik maddeleri konak bitkiden alan holoparazit bitkilerdir. Konak bitkiler genellikle bu bitkilerin saldırılarına karşı çeşitli fenolik bileşikler sentezlerler. Bu çalışmada konak bitki olarak kullanılanCarthamus glaucus Bieb. subsp. glaucus (Compositae) C.babylonica parazitliliğinin prostat kanseri ile direkt ilişkili olan STAT-3 genini inhibe eden çeşitli bileşikleri içeren çeşitli bir bitkidir. Çalışmada, C. Glaucus 'un fenolik bileşen içeriği üzerine olan etkisi araştırılmıştır. Parazit bitki ile enfekte olan ve olmayan C.glaucus bitkilerinin fenolik bileşen içerikleri LC/MS-MS ile analiz edilmiştir. Sonuçlar, savunma kimyasalları olarak bilinen kuinik asit, gallik asit, tr-kaffeik asit, hiperosid, kuersetinve naringenin içeriklerinde bir artış olduğunu göstermiştir.Bunun yanında tr-akonitik asit, vanillin, hesperidin, 4-OH-benzoik asit, salisilik asit ve kaemferol içerikleri küsküt bulaşması sonrası azalmıştır.

Anahtar Kelimeler: Cuscuta babylonica Aucher, carthamus glaucus bieb. subsp. glaucus (Compositae), fenolik bileşikler, LC/MS-MS

Dicle Üniversitesi, Fen Fakültesi, Biyoloji, Diyarbakir, Türkiye

Sorumlu yazar/Corresponding Author: Hilal SURMUŞ ASAN, hilalsuran@gmail.com 


\section{INTRODUCTION}

Parasitic plants are restrict the lives of earth plants. They are divided into two groups: hemiparasites are still able to make photosynthesis therefore rely only partially on a host plant and holoparasites that are completely dependent on solutes, metabolites, and photo assimilates, from their host crops. Cuscutacan be take into account an obligate holoparasite (Kaiser et al., 2015) because all of Cuscutaspecies depend (obviously) on a host plant to survive their life cycle. There are approximately 3.900 recognized parasitic plant species among the flowering plants, and Cuscuta spp. is one of the well-known and agriculturally most important genera (Westwood et al., 2010). Secondary metabolites that derived by host plants play an principal role in the interaction between parasitic weeds and their hosts (Bouwmeester et al., 2003).Water and nutrients are transferred uni-directionally through the haustorium from the vascular system of the host into the parasite. Besides, this organ also facilitates hormonal interactions between the two organisms (Kuijt and Toth 1976; Visser and Dorr, 1986; Stewart and Press 1990). Parasitic plants and hosts interactions usually parallel those between herbivores and plants (Pennings and Callaway, 2002).

Phenolics are usually produced and collected in the subepidermal sheets of plant tissues againist to stress factors and pathogens (Schmitz-Hoerner and Weissenbock, 2003; Clé et al., 2008). Parasitic plant affect and are affected by host plant physiology because of similar hormonal pathways between parasite and host plants (Pennings and Callaway, 2002). Because the host and parasite plants share the same primary physiology. Phenolic compounds one of the most prevalent groups of secondary metabolites found in the plants (Harborne, 1980; Boudet, 2007). They move as inhibitors, protective agents, pesticides and natural animal toxicants against phytophagous insects,herbivores, bacterial and fungal pathogens (Dakora and Phillips 1996; Ravin et al., 1989; Lattanzio et al., 2006). Plants requirement to phenolic compounds for growth, pigmentation, reproduction, resistance to pathogens and for several functions (Lattanzio et al., 2006).

Cuscuta babylonica Aucher parasitic plant used in this study, belong to the family Convolvulaceae and about 200 species have been described so far (McNeal et al., 2007). Most of them can cause serious problems for crops. Cuscuta has not leaves or roots, develops a haustorium and absorbs nutrients from host plants
(Furuhashi et al., 2011). It has known as Bostanbozan, Canavarotu, Bağbozan, Cinsac1, Eftimon, Gelinsac1, Kızıl sarmasık, Küsüt and Seytansacı in Anatolia (Baytop, 1997). Some of Cuscuta species are effective in the treatment of headache, itching, migraine, chronic catarrh, amnesia, epilepsy, expectorates, prolonged fever and constipation (Furuhashi et al., 2011).

The effect of parasitization does not always negatively on the host plant. For instance, infection of tomatoes by Cuscuta modified some plant hormones (e.g. salicylic acid) and can affect their defense system against insect herbivores (Runyon et al., 2008). Plants can perceive to pathogen attacks and respond by activating defence system (Karban and Baldwin, 1997; Dangl and Jones, 2001). Similarly, in a great number of study were revealed that the Cuscuta parasitzm caused to changes on host plants (Mishra and Sanwal, 1995; Runyon et al., 2008; Vurro et al., 2011; Furuhashi et al., 2012).

In this study, Carthamus glaucus Bieb. subsp. glaucus (Compositae) belong to family Asteraceae has been used as host plant. It is a winter plant anddevelops in the wheat fields (Meshram et al., 2011; Zadeh et al., 2011) and it is reported that this plant contains compounds inhibit the STAT- 3 gene is directly related with prostate cancer (Taglialatela-Scafati et. al., 2012).

The aim of this study was to research phenolic compounds differences of $C$. Glaucus plants which infected with $C$. babylonica. The results were compared with their respective controls for obtain and increase of desirable some phenolics that may use as medicinal compounds.

\section{MATERIALS and METHODS}

\section{Plant Material}

This work was carried out in Dicle University garden where $C$. glaucus grows naturally.

Germination of dodder seeds: Holoparasite $C$. babylonica seeds first submerged concentrated sulfuric acid for 30 minutes for scarification of hard seed coat. Than the seeds washed with tap water and put a cup with moist filter paper and deposited at $4^{\circ} \mathrm{C}$ refrigerator for 15 days. The stratified seeds were taken at $16{ }^{\circ} \mathrm{C}$ for germination.

After germination, naturally grown flowering $C$. glaucus has been infected with dodder for 15 days, and 
than infected C. glacus plants were collected and dried at room temperature. Non infected C. glaucus plants grown the same area were used as control group.

\section{Extraction}

The plant materials of $C$. Glaucus were dried at room temperature and than powdered. Ground samples $(0.2 \mathrm{~g})$ were extracted with chloroform $(10 \mathrm{~mL})$, and sonicated (Sanyo MSE-Soniprep 150, U.K.) for $5 \mathrm{~min}$. This treatment was repeated twice. The solvent was removed in vacuum, after removing chloroform; the samples were re-extracted with methanol $(10 \mathrm{~mL})$ in the sonicator for $5 \mathrm{~min}$. The methanol extraction was repeated three times. And the filtrates were collected and concentrated using a rotary vacuum evaporator (IKA, RV 10 DS 99).

The final samples were resolved in methanol and injected to LC-MS/MS (Shimadzu marka LCMS 8040 triple quadrupole mass spectrometry) after an appropriate dilution process. Phenolic compound analysis carried out according to the guidelines defined by Ertas et al.(2014) (Table.1).

Table 1. Analytical LC-MS/MS method parameters

\begin{tabular}{|c|c|c|c|c|c|c|c|c|c|}
\hline Analytes & $\mathbf{R T}^{\mathrm{a}}$ & $\begin{array}{l}\text { Parent ion } \\
(\mathrm{m} / \mathrm{z})^{\mathrm{b}}\end{array}$ & $\begin{array}{c}\text { Ioniza } \\
\text { tion } \\
\text { Mode }\end{array}$ & $\mathbf{R}^{2 \mathrm{c}}$ & RSD\% ${ }^{d}$ & $\begin{array}{l}\text { Linearity } \\
\text { Range (mg/L) }\end{array}$ & $\begin{array}{l}\text { LOD/LOQ } \\
(\mu \mathrm{g} / \mathrm{L})^{\mathrm{e}}\end{array}$ & $\begin{array}{l}\text { Reco- } \\
\text { very } \\
(\%)\end{array}$ & $\mathbf{U}^{\mathrm{f}}$ \\
\hline Quinic acid & 3.32 & 190.95 & $\mathrm{Neg}$ & 0.9927 & 0.0388 & $250-10000$ & $22.3 / 74.5$ & 103.3 & 4.8 \\
\hline Malic acid & 3.54 & 133.05 & $\mathrm{Neg}$ & 0.9975 & 0.1214 & $250-10000$ & $19.2 / 64.1$ & 101.4 & 5.3 \\
\hline tr-Aconitic acid & 4.13 & 172.85 & $\mathrm{Neg}$ & 0.9933 & 0.3908 & $250-10000$ & $15.6 / 51.9$ & 102.8 & 4.9 \\
\hline Gallic acid & 4.29 & 169.05 & $\mathrm{Neg}$ & 0.9901 & 0.4734 & $25-1000$ & $4.8 / 15.9$ & 102.3 & 5.1 \\
\hline $\begin{array}{l}\text { Chloroge } \\
\text { nic acid }\end{array}$ & 5.43 & 353 & $\mathrm{Neg}$ & 0.9932 & 0.1882 & $250-10000$ & $7.3 / 24.3$ & 99.7 & 4.9 \\
\hline $\begin{array}{l}\text { Protocate } \\
\text { chuic acid }\end{array}$ & 5.63 & 152.95 & $\mathrm{Neg}$ & 0.9991 & 0.5958 & $100-4000$ & $25.8 / 85.9$ & 100.2 & 5.1 \\
\hline tr- caffeic acid & 7.37 & 178.95 & $\mathrm{Neg}$ & 0.9942 & 1.0080 & $25-1000$ & $4.4 / 14.7$ & 98.6 & 5.2 \\
\hline Vanillin & 8.77 & 151.05 & $\mathrm{Neg}$ & 0.9995 & 0.4094 & $250-10000$ & $10.1 / 33.7$ & 99.2 & 4.9 \\
\hline $\begin{array}{l}\text { p-Coumaric } \\
\text { acid }\end{array}$ & 9.53 & 162.95 & $\mathrm{Neg}$ & 0.9909 & 1.1358 & $100-4000$ & $15.2 / 50.8$ & 98.4 & 5.1 \\
\hline Rutin & 10.18 & 609.1 & Neg & 0.9971 & 0.8146 & $250-10000$ & $17.0 / 56.6$ & 102.2 & 5.0 \\
\hline Hesp eridin & 9.69 & 611.1 & Poz & 0.9973 & 0.1363 & $250-10000$ & $21.6 / 71.9$ & 100.2 & 4.9 \\
\hline Hyperoside & 10.43 & 463.1 & $\mathrm{Neg}$ & 0.9549 & 0.2135 & $100-4000$ & $12.4 / 41.4$ & 98.5 & 4.9 \\
\hline $\begin{array}{l}\text { 4-OH Benzoic } \\
\text { acid }\end{array}$ & 11.72 & 136.95 & $\mathrm{Neg}$ & 0.9925 & 1.4013 & $25-1000$ & $3.0 / 10.0$ & 106.2 & 5.2 \\
\hline Salicylic acid & 11.72 & 136.95 & $\mathrm{Neg}$ & 0.9904 & 0.6619 & $25-1000$ & $4 / 13.3$ & 106.2 & 5.0 \\
\hline Quercetin & 14.48 & 300.9 & $\mathrm{Neg}$ & 0.9995 & 4.3149 & $25-1000$ & $2.0 / 6.8$ & 98.9 & 7.1 \\
\hline Naringenin & 14.66 & 270.95 & $\mathrm{Neg}$ & 0.9956 & 2.0200 & $25-1000$ & $2.6 / 8.8$ & 97.0 & 5.5 \\
\hline Luteolin & 15.43 & 284.95 & $\mathrm{Neg}$ & 0.9992 & 3.9487 & $25-1000$ & $5.8 / 19.4$ & 105.4 & 6.9 \\
\hline Kaempferol & 15.43 & 284.95 & $\mathrm{Neg}$ & 0.9917 & 0.5885 & $25-1000$ & $2.0 / 6.6$ & 99.1 & 5.2 \\
\hline Apigenin & 17.31 & 268.95 & $\mathrm{Neg}$ & 0.9954 & 0.6782 & $25-1000$ & $0.1 / 0.3$ & 98.9 & 5.3 \\
\hline Chrysin & 21.18 & 253 & Neg & 0.9965 & 1.5530 & $25-1000$ & $0.05 / 0.17$ & 102.2 & 5.3 \\
\hline
\end{tabular}

${ }^{\text {aRT: Retention time }}$

bParent ion $(\mathrm{m} / \mathrm{z})$ : Molecular ions of the standard compounds (mass to charge ratio)

${ }^{c} \mathrm{R}^{2}$ : coefficient of determination

${ }^{\mathrm{d}} \mathrm{RSD}$ : relative standard deviation

${ }^{e} \mathrm{LOD} / \mathrm{LOQ}(\mu \mathrm{g} / \mathrm{L})$ : Limit of deteection/Limit of quantification

${ }^{\mathrm{f}} \mathrm{U}(\%)$ : Percent relative uncertainty at $95 \%$ confidence level $(\mathrm{k}=2)$. 


\section{RESULTS and DISCUSSION}

Cuscuta is an obligate parasite attacking the shoot system of numerous species of dicotylednous plants, specially legume crops (Farah, 2010). Phenolic acids and lignin comprised a second type of defence mechanism against Cuscuta parasitism. They are chemical barriers used by certain incompatible hosts to resist the attack of parasitic weeds (Farah, 2007). Farah, (2010) indicated a rise in both phenolic acids and lignin contents with Cuscuta infestation in hyacinth bean and kidney bean. The increase in the levels of both chemicals in the infected kidney bean may be attributed to the fact that these chemicals were stimulated as part of the defence reactions of this crop against the penetration of haustorium into it is tissues. These results are in line with those of Arnaud et al.(1996) in Cusuta reflexa and Phaseolus vulgaris; Antonove and terBorg (1996) in Orobanche cumaua and Helianthus annuus, and Goldwasser et al. (1999) in Orobanche aegyptiaca and Viciaatropurpurea, who attributed the resistance of the host plants to a number of factors including phenolic compounds and lignin. Plant phenolic compounds are maintained in the nontoxic reduced state by antioxidants and stored in the cell vacuoles (Miles, 1999).

Host plant secretes various phenolic compounds, as a response to parasitic plant. The main ones are rosmarinic acid, caffeic acid, chlorogenic acid, tannic acid and quercetin (Lindroth and Batzli, 1984; Par and Tumlinson, 1999; Petersen et al., 2009; Serghini, 2001). In this study it was revealed that the Cuscuta parasitism caused an increase on amount of quinic acid (2.8 fold), gallic acid (2.4 fold), malic acid (1.01 fold), tr-caffeic acid (1.7 fold), hyperoside (2.4 fold), protocatechuic acid (PCA) (2.1 fold), quercetin (8.1 fold) and naringenin (3.1 fold) used as defence compounds. Likewise the amount of flavonoids luteolin (1.4 fold), apigenin (1.7 fold) and chrysin (1.05 fold) also improved(Table.2).

Our results very clearly show that the amount of PCA (2.1 fold) increased in infected plants. PCA is a natural phenolic acid and exist in several plants such as mushrooms and microorganisms (Williams et al., 2012; Nguyen et al., 2013; Delsignore 1997 et al.). It is known that the PCA has antiinflammatory and antioxidant (Liu et al., 2002; Syafni et al., 2012) and antibiotic activities (Nguyen et al., 2015). Besides antioxidative, nematicidal, and resistant effects, antibiotic and antibacterial activity of the PCA have been reported (Link et al., 1929; Syafni et al., 2012; Nguyen et al., 2013). Quinic acid is a metabolite related to metabolic response (inducible defense) to biotic stress (Murthy et al., 2009). It is reported that quinic acid and quercitol are present in high concentrations in wounded leaves of genus Quercus plants (GargalloGarriga et al., 2010). In this study it is revealed that the amount of quinic acid (2.8 fold) was increased in infected plants. Gallic acid is known to play an important role in insect-plant and plant-pathogen interactions (Arrantlrakrislmanet al.,1997). As our data, the amount of gallic acid (2.4 fold) was increased in infected plants. Similarly, it is reported that gallic acid showed chronic effects on growth, ingestion and utilization of food in Helicoverpa armigera, in relation to cotton (Ananthakrishnan et al., 1994). Flavonoids are the largest group of phenolics and they have antimicrobial and antioxidant properties (Lorenc-Kukula et al., 2005).Chlorogenic acid and hyperoside are present in several plants and have antioxidant capacity in plant defense system (Korkina, 2007; Leiss et al., 2009; Ngadze et al., 2012). The amount of chlorogenic acid and hyperoside increased (1.7 fold and 2.4 fold) after Cuscuta attack as our results. Quercetin is a flavonoid that has allelopathic feature (Inderjit and Gross, 2002; Weir et al., 2004). The rise of quercetin in the infected plants could be attributed primarily to it is toxicity and caused to reduction of plant growth (Lindroth and Batzli 1984). Lindroth and Batzli (1984) reported that the quercetin caused reduced growth rates. Our data showed that the quercetin increased 8.1 fold in infected plants compared to uninfected ones. It is reported that the concentration of the flavonol glycoside rutinusually remained unaffected after Cuscuta attack (Sham, 1993) our result also supported this finding.It was found that caffeic acid and other plant-derived phenolics had been transformed to active compounds against Streptococcus faecalis in the gut of Bombyx mori (Iizuka et al., 1974; Koike et al., 1979). In this study the amount of trcaffeic acid (1.7 fold) and p-coumaric acid(1.1 fold) were increased. Likewise, detection of phenolic acids in stems of broomrape, parasitizing faba bean, indicated the occurrence of chlorogenic acid, m-coumaric acid and caffeic acid at different stages of growth of the 
parasite (El-Akkad et al., 2002). Phenolic compounds, such as caffeic acid, and kaempferol-glycoside, are excellent inhibitors of IAA oxidation (Mumford et al., 1961; Krylov et al., 1994; Beckman, 2000; Mathesius, 2001). IAA accumulation is able to induce synthesis of flavonoids as a response to auxin accumulation (Peer and Murphy, 2007). Kaempferol is important part of the auxin dependent defence response (Likić et al.,2014). Howower, as our results, plants infected with Cuscuta exhibited lower concentration of kaempferol compared to control, with a 72.4 fold decrease. Antimicrobial effects of flavonoids have been defined to associate in allelopathic interactions between plants (Chou, 1999; Inderjit and Gross, 2000). But the roles of flavonoids and style of action are not yet completely understood. In our study, it is showed that a flavanon naringenin increased 3.1 fold in infected plants. It is found that the flavanone naringenin caused a recession on growth of gramineous plants (maize, rice, and Echinochloa oryzicola), and it is joined to the inhibition of 4-coumarate CoA ligase and lignification (Deng et al., 2004). Besides, it is reported that naringenin is produced after a pathogen attack in Oryza sativa L. (Jwa et al., 2006). In this study, the concentration of malic acid (MA) (1.01 fold) a slightly increased. Current studies proposed that the metabolic grades of low-MA have a remarkable role in initiating plant defense system (Klessig et al., 2000; Hückelhoven, 2007).

Cuscuta attacks caused to various morphological and physiological changes on the host plants (Serghini et al., 2001; Walters 2011). Salicylic acid (SA) has an foremost function in the defence response of plants (Dmitriev, 2003). SA is frequently synthesized in a response to pathogens (Loake and Grant, 2007). In the flowering phase, various plant hormones and chemical compounds are increase as well as SA and 4-OH benzoic acid (Khurana and Cleland, 1992; Martínez et al., 2004; Daayf et al., 2012).

It was showed that the amount of 4-OH benzoic acid (1.7 fold) and SA (1.7 fold) from C. glaucus plants that infected with Cuscuta attack and collected in the flowering phase were decreased compared with uninfected plants. These cases may be interpreted as evidence of inhibition reproduction of host by parasitic plants (Serghini et al., 2001; Pennings and Callaway,
2002; Furuhashi et al., 2011). It is known that the trans-aconitic acid has antirheumatic and diuretic properties (Schnitzler, 2007) althought the distribition of this compound is rare (Nierhaus and Kinzel, 1971). In infected plants, the trans-aconitic acid decreased about 1.4 fold relatively control plants. As our data, the amount of hesperidin (1.2 fold) decreased in infected plants. Hesperidin (Hsd) and hesperetin (Hst) have several biologycal activity such as antioxidant, antiinflammatory and anticancer effects. These substances play an important role in plant defense systems to combat different pathogens. Similarly, Soares et al., (2015) suggested that hesperidin plays an important role in the plant-pathogen interaction, probably as a phytoanticipin. In this stuy it was found that the amount of vanillin (2.2 fold) decreased in infected plants compared to control plants. Vanillin is the major component of natural vanilla, a well-known food and cosmetic additive and has antioxidant and antimutagenic properties. Their accumulation is highly sensitive to environmental conditions such as light, water and nutrient availability, and pathogen infection (Harvell and Bosland, 1997).

In several studies were revealed that the Cuscuta parasitism caused to changes on host plants (Mishra and Sanwal, 1995; Runyon et al., 2008; Vurro et al., 2011; Furuhashi et al., 2012). The effect of parasitic plants sometimes can be positively on the host plant. Plants have develop the ability to sense attacks and respond by activating defense system (Karban and Baldwin, 1997; Dangl and Jones, 2001). For instance it is exposed that Cuscuta changed some phytohormones (e.g. SA) and influenced their defense mechanism towards to insect herbivores on tomatoes (Runyon et al., 2008).

So we propose the phenolic changes that induced by parasitic attacks may be effective especially on the production of medicinally important compounds. For instance, our results revealed that the Cuscuta attack increased the amount of some phenolics in Carthamus. In addition, it is known that the Carthamus plant contains compounds inhibit the STAT- 3 gene is directly related to prostate cancer (Taglialatela-Scafati et al., 2012). Raza et al., (2015) revealed that Carthamus oxyacantha has terpenoids, natural phenolics and alcaloidal skeleton and has the DPPH activities. 


\section{CONCLUSION}

A higher concentrations of malic acid, quinic acid, chlorogenic acid, tr-aconitic acid, and hyperoside were obtained from C. glaucus Bieb. plants. On the other hand, lower concentrations of gallic acid, protocatechuic acid, tr- caffeic acid, vanillin, p-coumaric acid, hesperidin, 4-OH benzoic acid, quercetin,salicylic acid, naringenin, luteolin, kaempferol, apigenin, chrysin were obtained from C. glaucus plants that infected with Cuscuta.

As result of this study, when the amount of quercetin (8.1 fold), quinic acid (2.8 fold), gallic acid (2.4 fold), protocatechuic acid (2.1 fold), hyperoside (2.4 fold), malic acid (1.01 fold), chlorogenic acid (1.7 fold), tr- caffeic acid (1.7 fold), rutin (1.2 fold), p-coumaric acid (1.1 fold), naringenin (3.1 fold), luteolin (1.4 fold), apigenin (1.7 fold), and chrysin (1.05 fold) increased, the amount of kaempferol (72.4 fold), vanillin (2.2 fold), 4-OH benzoic acid (1.7 fold), salicylic acid (1.7 fold), tr-aconitic acid (1.4 fold), and hesperidin (1.2 fold) compounds decreased (Table 2) in infected C. glaucus plants.

Table 2. The phenolic changes in infected plants

\begin{tabular}{|c|c|c|c|c|c|}
\hline \multirow{2}{*}{ Compounds } & \multirow{2}{*}{$\begin{array}{c}\text { Parent } \\
\operatorname{ion}(\mathbf{m} / \mathbf{z})^{\mathrm{a}}\end{array}$} & \multirow{2}{*}{$\mathbf{M S}^{2}(\mathbf{C E})^{\mathrm{b}}$} & \multirow{2}{*}{$\begin{array}{l}\text { Ionization } \\
\text { Mode }\end{array}$} & \multicolumn{2}{|c|}{$\operatorname{Amount}\left(\mu \mathrm{g}\right.$ analyte/g extract) ${ }^{c}$} \\
\hline & & & & Control & Infected plant \\
\hline Quinic acid & 190.95 & $85(22) .93(22)$ & Neg & $7794.62 \pm 37.4146$ & $21977.30 \pm 10.549$ \\
\hline Malic acid & 133.05 & $115(14) .71(17)$ & Neg & $191553.83 \pm 101.52$ & $194456.14 \pm 103.06$ \\
\hline tr-Aconitic acid & 172.85 & $85(12) .129(9)$ & Neg & $4222.33 \pm 206.89$ & $2970.00 \pm 145.53$ \\
\hline Gallic acid & 169.05 & $125(14) .79(25)$ & Neg & $4.165 \pm 0.212$ & $10.12 \pm 0.516$ \\
\hline Chlorogenic acid & 353 & $191(17)$ & Neg & $8199.86 \pm 401.79$ & $13943.77 \pm 683.24$ \\
\hline Protocatechuic acid & 152.95 & 109(16).108 (26) & Neg & $40.389 \pm 2.059$ & $86.721 \pm 4.422$ \\
\hline tr- caffeic acid & 178.95 & $\begin{array}{l}135(15) .134(24) .89 \\
(31)\end{array}$ & Neg & $79.844 \pm 4.151$ & $137.603 \pm 7.155$ \\
\hline Vanillin & 151.05 & $136(17) .92(21)$ & $\mathrm{Neg}$ & $34.656 \pm 1.698$ & $15.374 \pm 0.753$ \\
\hline p-Coumaric acid & 162.95 & $119(15) .93(31)$ & Neg & $26.338 \pm 1.343$ & $29.683 \pm 1.513$ \\
\hline Rutin & 609.1 & $\begin{array}{l}300(37) .271 \text { (51). } 301 \\
(38)\end{array}$ & Neg & $94.649 \pm 4.732$ & $119.947 \pm 5.997$ \\
\hline Hesperidin & 611.1 & $303(24) .465(12)$ & $\mathrm{Poz}$ & $511.851 \pm 25.08$ & $422.168 \pm 20.68$ \\
\hline Hyperoside & 463.1 & $300(27) .301(26)$ & Neg & $2152.131 \pm 105.45$ & $5276.118 \pm 258.52$ \\
\hline 4-OH Benzoic acid & 136.95 & 93 (17).65 (27) & Neg & $32.118 \pm 1.670$ & $18.521 \pm 0.963$ \\
\hline Salicylic acid & 136.95 & $93(16) .65(31) .75(30)$ & Neg & $33.787 \pm 1.68$ & $19.807 \pm 0.99$ \\
\hline Quercetin & 300.9 & $\begin{array}{l}\text { 179(19).151 (21).121 } \\
(28)\end{array}$ & $\mathrm{Neg}$ & $42.260 \pm 3.00$ & $343.350 \pm 24.37$ \\
\hline Naringenin & 270.95 & $\begin{array}{l}151(18) .119(24) .107 \\
(26)\end{array}$ & Neg & $25.839 \pm 1.42$ & $81.893 \pm 4.50$ \\
\hline Luteolin & 284.95 & $\begin{array}{l}217(25) \cdot 199 . \\
(28) .175(29) .151(25)\end{array}$ & $\mathrm{Neg}$ & $72.630 \pm 5.01$ & $104.701 \pm 7.22$ \\
\hline Kaempferol & 284.95 & $\begin{array}{l}217(29) .133(32) .151 \\
(23)\end{array}$ & Neg & $75.834 \pm 3.94$ & $1.047 \pm 0.05$ \\
\hline Apigenin & 268.95 & 151(25).117(35) & Neg & $770.217 \pm 40.82$ & $1309.9 \pm 69.42$ \\
\hline Chrysin & 253 & $\begin{array}{l}143(29) .119(32) \cdot 107 \\
(26)\end{array}$ & Neg & $0.767 \pm 0.04$ & $0.810 \pm 0.04$ \\
\hline
\end{tabular}




\section{ACKNOWLEDGE}

We thank Mr. Mustafa Abdullah Yilmaz (Dicle University Science and Technology Research and Application Center (DUBTAM), Dicle University) for technical assistance.

\section{REFERENCES}

Ananthakrishnan TN, Daniel Wesley S, John Peter A, Marimuthu S, 1994. Ecological interactions of Helicoverpa armigera and its natural enemies. Int J Ecol Environ Sci 20: 317-331.

Antonova TS, terBorg ST, 1996. The role of peroxidase in the resistance of sunflower against Orobanche cumane in Russia. Weed Research 36: 113-121.

Arnau M, Renaudin S, Fer A, 1996. Investigations into the cellular and biochemical events involed in the resistance of a legume, (Phaseolus vulgaris) to a parasitic higher plant, Cuscuta reflexa. M.T. Moreno J.I 592-596.

Arrantlrakrislman TN, 1997. Gallic and salicylic acids: sentinels of plant defence against insects. Current Science 73.

Baytop T, 1997. Türkçe bitki adları sözlügü̈; Türk Dil Kurumu Basımevi: Ankara Türkiye p 578.

Beckman CH, 2000. Phenolic-storing cells: keys to programmed cell death and periderm formation in wilt disease resistance and in general defence responses in plants? Physiol Mol Plant P 57: 101-110.

Bennett RN, Wallsgrove RM, 1994. Secondary metabolites in plant defense mechanisms. New Phytol 127: 617-633.

Boudet A, 2007. Evolution and current status of research in phenolic compounds. Phytochemistry 68: 2722-2735.

Bouwmeeste HJ, Matusova R, Zhongkui S, Beale MH, 2003. Secondary metabolite signalling in host-parasitic plant interactions. Curr Opin Plant Biol 6: 358-364.

Chou CH, 1999. Roles of allelopathy in plant biodiversity and sustainable agriculture. Crit Rev in Plant Sci 18: 609- 636.

Clé C, Hill LM, Niggewe R, Martin CR, Guisez Y, Prinsen E, Jansen MAK, 2008. Modulation of chlorogenic acid biosynthesisin Solanum lycopersicum; consequences for phenolic accumulationand UV-tolerance. Phytochemistry 69: 2149-2156.

Daayf F, El Hadrami A, El-Bebany AF, Henriquez MA, Yao Z, Derksen H, Adam LR, 2012. Phenolic compounds in plant defense and pathogen counter-defense mechanisms. Rec Adv Polyphen Res3 191.

Dakora FD, Phillips DA, 1996. Diverse functions of isoflavonoids in legumes transcend anti-microbial definitions of phytoalexins. Physiol Mol Plant P49 1-20.

Dang1 JL, Jones JDG, 2001. Plant pathogens and integrated defence responses to infection. Nature 411: 826-833.

Delsignore A, Romeo F, Giaccio M, 1997. Content of phenolic substances in basidiomycetes. Mycol Res 101: 552-556.
Deng F, Aoki M, Yogo Y, 2004. Effect of naringenin on the growth and lignin biosynthesis of gramoineous plants. Weed Biol Manag 4: 49-55.

Dmitriev AP, 2003. Signal molecules for plant defense responses to biotic stress. Russ J of Plant Physl 50: 417- 425.

El-Akkad SS, Hassan E A, Ali M E, 2002. Phenolic acid changes during Orobanche parasitism on faba bean and some other hosts. Egypt J Biol 4: 37-44.

Ertas A, Boga M, Yılmaz MA, Yesil Y, Hasimi N, Kaya MS, Kolak U, 2014. Chemical compositions by using LC-MS/MS and GC-MS and biological activities of Sedum sediforme, Jacq. Pau. J Agr Food Chem 62: 4601-4609.

Farah AF, 2007. Resistance of some plant species to field dodder, Cuscuta campestris. African corp science conference Proceedings 8: 913-917.

Farah AF, 2010. The response of two legume crops, hyacinth bean and kidney bean to the parasitism of field dodder, (Cuscuta campestris).

Furuhashi T, Fragner L, Furuhashi K, Valledor L, Sun X, Weckwerth W, 2012. Metabolite changes with induction of Cuscuta haustorium and translocation from host plants. J Plant Interact 7: 84-93.

Furuhashi T, Furuhashi K, Weckwerth W, 2011. The parasitic mechanism of the holostem parasitic plant Cuscuta. J Plant Interact 6: 207-219.

Gargallo-Garriga A, Sardans JV, Pérez-Trujillo M, Parella T, Seco R, Filella I, Peñuelas J, 2010. Metabolomic responses of Quercus ilex seedlings to wounding simulating herbivory. SMASH Conference Santiago de Compostela Spain.

Glodwassser Y, Hershenhorn HJ, Plalhire D, Kleifeld Y, Rubin B, 1999. Biochemical factors involved in vetch resistance to Orobanche aegyptiaca. Physiol Mol Plant 54: 87-96.

Harborne JB, 1980. Plant phenolics. In: Encyclopedia of Plant physiol8

Harvell KP, Bosland PW, 1997. The environment produces a significant effect on pungency of chiles. Hort Science 32: 1292-1297.

Hückelhoven R, 2007. Cell wall-associated mechanisms of disease resistance and susceptibility. Annu Rev Phytopathol 45: 101-127.

Iizuka L, Ko1ke S, Mitzutanı J, 1974. Antibacterial substances in feces of silkworm larvae reared on mulberry leaves. Agric Biol Chem 38: 1549-1550.

Inderjit S, Gross E, 2000. Plant phenolics: potential role in aquatic and terrestrial ecosystems. In Polyphenols, Martens S Treutter D and Forkmann G eds. 206-234.

Jwa NS, Agrawal GS, Tamogami S, Yonekura M, Han O, Iwahashı H, Rakwal R, 2006. Role of defense/stress-related marker genes proteins and secondary metabolites in defining rice selfdefense mechanisms. Plant Physiol Biochem 44: 261-273.

Kaiser B, Vogg G, Fürst UB, Albert M, 2015. Parasitic plants of the genus Cuscuta and their interaction with susceptible and resistant host plants. Frontiers in plant science 6 .

Karban R, Baldwin IT, 1997. Induced Responses to Herbivory. University of Chicago Press Chicago 
Khurana JP, Cleland CF, 1992. Role of salicylic acid and benzoic acid in flowering of a photoperiod-insensitive strain Lemna paucicostata LP6. Plant physiol 100: 1541-1546.

Klessig DF, Durner J, Noad R, Navarre DA, Wendehenne D, Kumar D, Zhou JM, Shah J, Zhang S, Kachroo P, 2000. Colloquium paper: nitric oxide and salicylic acid signaling in plant defense. Proc Natl Acad Sci 97: 8849-8855.

Koike S, Hzuka T, Mizutanl J, 1979. Determination of caffeic acid in the digestive juice of silkworm larvae and its antibacterial activity against the pathogenic Streptococcusfaecalis AD-4. Agric Biol Chem 43: 1727-1731.

Korkina LG, 2007. Phenylpropanoids as naturally occurring antioxidants: from plant defense to human health. Cell Mol Biol 53: 15-25.

Krylov SN, Krylova SM, Chebotarev IG, Chebotareva AB, 1994. Inhibition of enzymatic indole-3-acetic acid oxidation by phenols. Phytochemistry 36: 263-267.

Kuijt, JToth R, 1976. Ultrastructure of angiosperm haustoria A review. Annuals of Botany 401:121-1130

Lattanzio V, Lattanzio VM, Cardinali A, 2006. Role of phenolics in the resistance mechanisms of plants against fungal pathogens and insects. Phytochemistry 661: 23-67.

Leiss KA, Maltese F, Choi YH, Verpoorte R, Klinkhamer PG, 2009. Identification of chlorogenic acid as a resistance factor for thrips in chrysanthemum. Plant Physiol 150: 1567- 1575.

Likić S,Šola I,Ludwig-Müller J,Rusak G, 2014. Involvement of kaempferol in the defence response of virus infected Arabidopsis thaliana. Eur J Plant Pathol 138: 257-271.

Lindroth RL, Batzli GO, 1984. Plant phenolics as chemical defenses: effects of natural phenolics on survival and growth of prairie voles, (Microtus ochrogaster).J Chem Ecol 10: 229-244.

Link KP, Angell HR, Walker JC, 1929. Isolation of protocatechuic acid from pigmented onion scales and its significance in relation to disease resistance in onions. J Biol Chem 81: 369 375 .

Liu CL, Wang JM, Chu CY, Cheng MT, 2002. In vivo protective effect of protocatechuic acid on tert-butyl hydroperoxideinduced rat hepatotoxicity. Food Chem Toxicol 40: 635-641.

Loake G, Grant M, 2007. Salicylic acid in plant defence-the players and protagonists. Curr Opin Plant Biol 10: 466-472.

Lorenc-Kukula K, Jafra S, Oszmı́nsk1 I, Szopa J, 2005. Ectopic Expression of Anthocyanin 5-O-Glucosyltransferase in Potato Tubers Causes Increased Resistance to Bacteria. J Agrie Food Chem 5: 3 272-281.

Martínez C,Pons E, Prats G, León J, 2004. Salicylic acid regulates flowering time and links defence responses and reproductive development. The Plant Journal 37: 209-217.

Mathesius U, 2001. Flavonoids induced in cells undergoing nodule organogenesis in white clover are regulators of auxin breakdown by peroxidase. J Expe Bot 52: 419-426.

McNeal JR, Arumugunathan K, Kuehl JV, Boore JL, de Pamphilis $\mathrm{CW}, 2007$. Systematics and plastid genome evolution of the cryptically photosynthetic parasitic plant genus Cuscuta, (Convolvulaceae). BMC Biol. 5: 1-19.
Miles PW, 1999. Aphid saliva. Biol Rev Camb Philos Soc 74: 4185.

Mishra S, Sanwal GG, 1995. Changes in lipid composition of Brassica siliquae upon infection by Cuscuta. J Plant Physiol 146: 303-306.

Mumford FE, Smith DH, Castle JE, 1961. An inhibitor of indoleacetic acid oxidase from pea tips. Plant physiol 36: $752-756$.

Murthy PS, 2009. Eur Food Res Technol 229- 645.

Ngadze E, Icishahayo D,Coutinho TA, van der Waals JE, 2012. Role of polyphenol oxidase peroxidase phenylalanine ammonia lyase chlorogenic acid and total soluble phenols in resistance of potatoes to soft rot. Plant Dis 96: 186-192.

Nguyen DMC, Seo DJ, Kim K, Yv Park RD, 2013. Nematicidal activity of 34-dihydroxybenzoic acid purified from Terminalia nigrovenulosa bark against Meloidogyne incognita. Microb Pathog 59: 52-59.

Nguyen XH, Naing KW, Lee YS, Moon JH, Lee JH, Kim KY, 2015. Isolation and characteristics of protocatechuic acid from Paenibacillus elgii HOA73 against Botrytis cinerea on strawberry fruits. J Basic Microb55: 625-634.

Nierhaus D, Kinzel H, 1971. Comparative investigations on organic acids in leaves of higher plants. ZPfl anzenphysiol64: 107123.

Paré PW, Tumlinson JH, 1999. Plant volatiles as a defense against insect herbivores. Plant physiol 121: 325-332.

Peer WA, Murphy AS, 2007. Flavonoids and auxin transport: modulators or regulators? Trends Plant Sci 12: 556-563.

Pennings SC, Callaway RM, 2002. Parasitic plants: parallels and contrasts with herbivores.Oecologia131:479-489.

Petersen M, Abdullah Y, Benner J, Eberle D, Gehlen K, Hücherig S, Wolters S, 2009. Evolution of rosmarinic acid biosynthesis. Phytochemistry70: 1663-1679.

Ravin H, Andary C,Kovacs G,Molgaard P, 1989. Caffeic acid esters as in vitro inhibitors of plant pathogenic bacteria and fungi. Biochem Syst Ecol 17: 175-184.

Runyon JB, Mescher MC, De Moraes CM, 2008. Parasitism by Cuscuta pentagona attenuates host plant defenses against insect herbivores. Plant Physiol 146: 987-995.

Sahm A,Czygan FC, Proksch P, 1993. Resistance of tomato, Lycopersicon esculentum to dodder, (Cuscuta reflexa). In International Symposium on Natural Phenols in Plant Resistance 381: 650-653.

Schmitz-Hoerner R, Weissenbock G, 2003. Contribution of phenolic compounds to the UV-B screening capacity of developing barley primary leaves in relation to DNA damage and repair under elevated UV-B levels. Phytochemistry64: 243-255.

Schnitzler M, Petereit F, Nahrstedt A, 2007. Trans-Aconitic acid glucosylflavones and hydroxycinnamoyltartaric acids from the leaves of Echinodorus grandiflorus ssp. aureus a Brazilian medicinal plant. Revista Brasileira de farmacognosia 17: 149154.

Serghini K,de Luque AP, Castejón $\square$ Muñoz M,García $\square$ Torres L,Jorrín JV, 2001. Sunflower, (Helianthus annuus) L. response to broomrape, (Orobanche cernua) Loefl. parasitism: induced synthesis and excretion of $7 \square$ hydroxylated simple coumarins. J Expe Bot 52: 2227-2234. 
Soares MS, da Silva DF, Forim MR, Fernandes JB, Vieira PC, Silva DB, Machado MA, 2015. Quantification and localization of hesperidin and rutin in Citrus sinensis grafted on C. limonia after Xylella fastidiosa infection by HPLC-UV and MALDI imaging mass spectrometry. Phytochemistry.

Stewart GR, Press MC, 1990. The physiology and biochemistry of parasitic angiosperms. Annu Rev Plant phys 41: 127-151.

Syafni N, Putra DP, Arbain D, 2012. 34-Dihydroxybenzoic acid and 34-dihydroxybenzaldehyde from the fern Trichomanes chinense; isolation antimicrobial and antioxidant properties. Indo J Chem 12: 273-278.

Taglialatela-Scafati O,Pollastro F, Cicione L, Chianese G, Bellido ML, Munoz E, Appendino G, 2012. Stat-3 inhibitory bisabolanes from Carthamus glaucus. J Nat Prod 75: 453-458.

Visser JH, Dorr I, 1986. The haustorium In Parasitic weeds in agriculture1 Striga, ed Musselman L J. CRC Press Inc Boca Raton, (Bell E.A. and Charlwood B.V eds) 329-395.
Vurro E, Ruotolo R, Ottonello S, Elviri L, Maffini M, Falasca G, di Toppi LS, 2011. Phytochelatins govern zinc/copper homeostasis and cadmium detoxification in Cuscuta campestris parasitizing Daucus carota. Environ Exp Bot7: 26-33.

Walters DR. Why Do Plants Need Defenses? Plant Defense 1-14.

Weir TL, Park SW, Vivanco JM, 2004. Biochemical and physiological mechanisms mediated by allelochemicals. Curr Opin Plant Biol 7: 472-479.

Westwood JH, Yoder JI, Timko MP, Depamphilis CW, 2010. The evolution of parasitism in plants. Trends Plant Sci 15: 227235.

Williams KM, Martin WE, Smith J, Williams BS, 2012. Production of protocatechuic acid in Bacillus thuringiensis ATCC33679. Int J Mol Sci 13: 3765-3772. 
